\title{
Research on Media Literacy of Ideological and Political Educators of Colleges and Universities in the New Era
}

\author{
$\mathrm{Lu} \mathrm{Li}$ \\ Northwestern Polytechnical University \\ Xi'an, P.R. China 710072
}

\begin{abstract}
In the new era, General Secretary Xi Jinping, facing the rapid development and popularization of new media, gives specific instructions to ideological and political education in colleges and universities: It is necessary to use new media and new technology to get the work moving, promote the high integration of traditional advantages of ideological and political work with information technology, and enhance the sense of the times and attraction. By learning the general secretary's speech spirit, the author further realizes the important role and times significance of new media in the ideological and political education of colleges and universities. And the foundation of ideological and political education of colleges and universities lies in the concrete ideological and political educators of Party and government leaders and teachers in colleges and universities, and the level of their own media literacy is the key to influencing the integrated development of new media and ideological and political education of colleges and universities. With such thinking, this study aims to carry out innovative research on how to improve the media literacy of ideological and political educators of colleges and universities in the new era. In the specific research, by collocating and analyzing the existing research results in the past ten years, the author carries out systematic research mainly from two macro aspects of "establishing the concept of integrated development and exploring the integrated development mechanism of ideological and political education of colleges and universities and new media" and "building an innovative working platform and enhancing the effectiveness and pertinence of ideological and political education of colleges and universities".
\end{abstract}

Keywords-new era; ideological and political educators of colleges and universities; media literacy

\section{INTRODUCTION}

According to CNNIC data, as of December 2017, the number of netizens in China reached 772 million with a popularizing rate of $55.8 \%, 4.1 \%$ higher than the global average (51.7\%) and 9.1\% higher than the Asian average $(46.7 \%)$. Wherein, the number of mobile phone netizens reached 753 million, and the proportion of mobile phone users among netizens increased from $95.1 \%$ in 2016 to $97.5 \%$; the usage rates of desktop computers, notebook computers and tablet computers have all decreased, and the use of mobile phones continue to takes a dominant position among all personal Internet devices. The data also suggests that netizens are mainly 10-39 years old, and 10-year-old to 39 -year-old netizens account for $73.0 \%$ of all netizens, of them the netizens in the 20-29 age group account for the highest proportion, reaching up to $30.0 \%$; the ratios of groups aged 10-19 years old and 30-39 years old are 19.6\% and $23.5 \%$, respectively, which are basically the same as those at the end of 2016. [1] Through data analysis, I can recognize that new media has developed in leaps and bounds with an extremely high popularizing rate, and young people are the main group of new media.

Faced with this realistic background, General Secretary $\mathrm{Xi}$ Jinping makes specific instructions on ideological and political education in colleges and universities in light of the development reality of new media: It is necessary to use new media and new technology to get the work moving, promote the high integration of traditional advantages of ideological and political work with information technology, and enhance the sense of the times and attraction. [2]By learning the general secretary's speech spirit, the author further realizes the important role and times significance of new media in the ideological and political education of colleges and universities. And the foundation of ideological and political education of colleges and universities lies in the concrete ideological and political educators of Party and government leaders and teachers in colleges and universities, and the level of their own media literacy is the key to influencing the integrated development of new media and ideological and political education of colleges and universities. With such thinking, this study aims to carry out innovative research on how to improve the media literacy of ideological and political educators of colleges and universities in the new era.

\section{CONCEPT DEFINITION}

\section{A. New Era}

New era here refers to the new era of socialism with Chinese characteristics, which is essentially the era when the Chinese nation becomes strong. On October 18, 2017, General Secretary Xi Jinping made a highly concise and scientific summary of the essential connotation of the new era of socialism with Chinese characteristics in the report of the 19th National Congress of the CPC: "this new era is an 
era serving as a link between past and future, carrying forward our cause and forging ahead into the future and continuing to win the great victory of socialism with Chinese characteristics under new historical conditions, an era of building a well-off society in an all-round way and further building a modern socialist power comprehensively, an era in which people of all ethnic groups work together to create a better life and gradually realize common prosperity of all people, an era all Chinese people, all united and with one mind, strive to realize the Chinese dream of great rejuvenation of the Chinese nation, and an era our country is getting closer to the center of the world stage and making greater contributions to mankind. "[3]

\section{B. Ideological and Political Educators of Colleges and Universities}

The implementation of ideological and political education is the core responsibility of ideological and political educators of colleges and universities. Therefore, first of all, we should have a basic understanding of the concept of "ideological and political education". "Ideological and political education" has evolved continuously from the concepts of "propaganda work", "political work", "ideological work", "political education" and "ideological and political work", etc.[4] It is a practical activity formed by the Chinese Communist Party in the course of specific revolutionary development in combination with China's actual development. In the "The Theory and Practice of Ideological and Political Education for College Students" published by the Ideological and Political Work Department of the Ministry of Education in 2009 there is such an exposition on it: "ideological and political education is the process in which educators and educatees, according to the needs of society and its own development, continuously improve their ideological, political and moral qualities and promote all-round development in the process of adapting to and promoting social development under the guidance of correct ideological, political and moral theories. "[5] But in the specific research, the interpretation of the concept of "ideological and political education" has not formed a unified understanding. For instance, Qiu Weiguang believes that ideological and political education is "an education practice to cultivate and shape the ideological and moral qualities of a certain new comers in society", and restricted and influenced by social economy, politics and culture, it includes ideological education, political education, and moral education. [6]Wang Lizhan considers that ideological and political education is "an educational project in which the society systematically and directionally guides people to form ideological and political views in line with the requirements of the specific society and the times."[7] Lu Qingren holds that ideological and political education is a kind of social practice, that is, "in order to achieve a certain political goal, a certain class or political group purposefully exerts ideological influence on people, hoping to change people's thoughts and then guide people's social behaviors." [8] Chen Binggong views that ideological and political education is "the comprehensive educational practice of ideology, morality and psychology that a certain class or political group carries out in order to realize its political goals and tasks, with political and ideological education as its core and focus." [9]Liu Shulin and Chen Lishi deem that ideological and political education is "a practical activity in which a certain class, political party and social group exerts certain ideological influence on all members of society through educational activities in order to realize their own political goals so that they can accept and form certain political concepts and behavioral awareness, thus dominating them to act consciously." [10]Ideological and political education is "a social practice activity in which a certain class, political party and social group exerts purposeful, planned and organized influence on their members with certain ideological concepts, political viewpoints and moral norms so that they can form ideological and moral qualities in compliance with the needs of a certain society and class." [11]Later, the scholar Zhang Yaocan switched to the paradigm of human studies in his specific research and optimized his concepts. He believes that ideological and political education is "a social practical activity in which a certain class, association, organization, group and their members carry out ideological and emotional exchanges and interactions through a variety of ways, guiding their members to absorb and identify with certain social ideas, political views and moral norms, and promoting their members' balanced and coordinated development in knowledge, emotion, character will, faith and conduct, as well as their ideological and moral self-construction. "[12]

Through the above understanding, we have got a basic understanding of the concept of "ideological and political education". Therefore, ideological and political educators of colleges and universities, as the name implies, refers to workers engaged in ideological and political education in institutions of higher learning, and the concrete manifestations are: party Committee secretaries and other school leaders, department secretaries, Youth League general branches, teachers of ideological and political education courses, political instructors and other personnel related to ideological and political education in various colleges and universities.

\section{Media Literacy}

The concept of media literacy is foreign and originated from the west. In 1933, British cultural scholars F.R.Leavis and Denys Thompson published the cultural criticism books Culture and Environment: The Training of Critical Awareness, which first proposed the concept of "media literacy" and advocated media literacy education. Compared with the west, the research on media literacy in China's academic circles started relatively late. In 1997, Buwei of Journalism Institute, Chinese Academy of Social Sciences put forward the concept of "media education" in his paper "On the Significance, Content and Method of Media Education". In the study, Buwei defined media education as "education to cultivate citizens' media literacy". It includes four aspects: first of all, to understand basic media knowledge and how to use media. Moreover, learn to judge the significance and value of media messages. Thirdly, to learn the knowledge and skills to create and disseminate information. Finally, to understand how to effectively use 
mass media to develop ourselves. She considers that the ideal situation of media education is that the audience's media usage will become a driving force for their development and will not be reduced to the slave of mass media or message due to media usage. [13]Afterwards, with the development of media technology and the popularization of electronic media, academic circles increasingly turned their research perspective to "media literacy".

Up till now, the concept of "media literacy" has not yet formed a unified understanding. The definition given by the British media scholar David Buckingham is: "the term of media literacy refers to the knowledge, skills and abilities needed to use and interpret media. " [14]American scholar W.James Potter considers that media literacy refers to a perspective, we use it to contact the media and explain the meaning of the messages we encounter. It consists of three cornerstones, namely, personal positioning (goals and motives), knowledge structure (media effect), skills (analysis, evaluation, classification, induction, deduction, synthesis, extraction). [15]In his book Introduction to Mass Communication 8 e Media Literacy and Culture, Stanley.J.Baran follows the scholar Art Silverblatt's understanding of media literacy, and believes that media literacy should have the following seven basic elements, respectively: 1 . critical thinking skills to enable audience members to expand their ability to make judgement independently in respect of media contents; 2 . understand the process of mass communication; 3 . understand the impact of media on individuals and society; 4 . have strategies to analyze and discuss media information; 5. realize that media content is the text that understands our culture and life; 6 . cultivate and promote our ability to enjoy, understand and appreciate media content; 7. develop effective and reliable production skills. [16]

For researchers in our country, the understandings of "media literacy" mostly continue the western concept with relatively high similarity. Zhang Zhi'an and Shen Guolin deem that media literacy refers to people's ability to interpret and criticize various media information and use media information for personal life and social development. [17]Zhang Guanwen and Yu Jian believe that media literacy refers to people's literacy to correctly judge and evaluate the significance and function of media information and effectively create and disseminate information. [18]In this study, considering the agreement with the research, the author decides to follow the definitions of media literacy given by Chinese scholars Zhang Zhi'an and Shen Guolin.

\section{RESEARCH STATUS}

The cross study of "ideological and political education" and "media literacy" started in 2005 and there are few academic achievements at present. Hu Zhongqing was the earliest scholar to study it, he proposes that it is an important and brand-new topic of ideological and political education in colleges and universities in the new era to correctly analyze the positive and negative effects of modern media on college students, incorporate media literacy education into the ideological and political education system of colleges and universities, and develop ideological and political education in terms of educational content and training objectives. [19]He specifically discusses the establishment of mechanisms, the development of media literacy education, the use of existing resources, and the enhancement of theoretical research, etc.; Wang Yanxia carries out relevant research with the transition from planned economy to market economy as the time node, and she advocates to make college students to understand the functions of the media to reproduce and reconstruct reality through appropriate educational methods and means, recognize the dual influence of the media on society, judge the multiple meanings of media information and form a benign interactive relationship with the media so that college students can actively adapt to the new situation and new environment by participating in newspaper editing, radio and television programs, advertisements, webpage making, etc. through classroom teaching, media practice and subject research, etc., and continuously explore effective ways of ideological and political education for college students; [20]Based on an indepth analysis of the current situation of college students' media literacy under the network communication, this paper expounds that the content system of media literacy education of college students includes their ability to cognize the network media, their ability to interpret and evaluate the network information, their ability to create and communicate, and their ability to develop and perfect themselves by using the network media information. It proposes to strengthen college students' media literacy education and expand the new field of college students' ideological and political education from the following three aspects: opening media literacy education courses, improving media literacy of ideological and political educators of colleges and universities and paying attention to the close combination of media literacy education and ideological and political education of college students; [21]Ji Haiju holds that college students have a lack of rational knowledge of the media and are lack of macro-knowledge of new media literacy education. Their ability to obtain information is not strong, and most people only use it as a way of entertainment and leisure; their ability to effectively use media resources is relatively weak and they cannot be correctly identify and use the resources; their ability to judge and understand is relatively poor, and they have relatively weak ability to screen malicious information; their ability to interact with the media is not strong, and they are not good at using new media; their ability to use new media is relatively low, their knowledge of moral rules of the media is relatively vague, and besides, they have relatively weak network ethics and legal awareness. The main suggestions are to establish and perfect the working mechanism of new media literacy education of college students, build a carrier platform for new media literacy education, focus on improving the new media literacy of educators, insist on the organic combination of classroom education and social practice, and strengthen theoretical research and academic exchange of new media literacy education; [22]Luo Guogan considers that media literacy education and ideological and political education have the same object, consistent purpose, relevant content, common methods, category of the same root and similar ways, which provides a great possibility for the 
combination of the two. In the light of the requirements of quality education itself and combined with the development law of ideological and political education, the requirement for the localized development of media literacy education in China makes it inevitable to combine the two. Incorporate media literacy education into the ideological and political education system, guide media literacy education with the content of ideological and political education, and the teaching process of the effective combination of the two can be divided into three stages: theoretical study, thinking analysis and practical operation.[23]

Since 2011, scholars have begun to carry out specific research on the media literacy of ideological and political educators. Feng Xin thinks that most domestic scholars have focused their attention on the exploration of "media literacy education" for students, but have neglected the necessity of developing media literacy education for ideological and political educators of colleges and universes. He proposes to improve the overall quality of the ideological and political education team from the following aspects: attaching importance to the popularization of basic media knowledge, strengthening the awareness of media functions, and focusing on the cultivation of media application ability, etc.; [24]In Liu Yafei's view college teachers have a special role and relatively high social status. From the perspective of ideological and political education, they are not only the target of ideological and political education, but also the implementer of ideological and political education and the pathfinder for the vast number of young students. While in the media environment, they are not merely the audience of the media but the disseminators and creators of media information. They play the role of "opinion leaders" among college students, and the level of their media literacy is not only related to themselves but affects the level of college students' media literacy. Therefore, it is of great practical significance and theoretical value to carry out the research on the media literacy education of university teachers from the perspective of ideological and political education; [25]Su Weigang considers that "Internet+education" takes the selfmedia platform as its carrier, highlights the optimization of ideological and political education, and focuses on cultivating scientific thinking and developing innovative thinking. On the one hand, it stimulates the vitality of ideological and political education of college students through inspiration, exploration and training so as to realize the in-depth integration of "Internet+education". On the other hand, "Internet+education" provides an information game platform for ideological and political educators of colleges and universities and college students. It weakens the discourse power of ideological education while forming a "public discourse energy field" and deconstructs the functions of thinking education, making it step into the "Tacitus trap" day by day. Therefore, under the mode of "Internet+education", ideological and political educators of colleges and universities urgently need to reshape their discourse power and pay attention to the education of scientific thinking; establish a self-media database and implement media education; optimize and integrate information resources and emphasize giving play to microcapabilities; cultivate media morality and enhance micro- confidence so as to optimize their own media literacy; [26]In Luo Yuyun's opinion, ideological and political educators of colleges and universities play a vital leading role in ideological and political education and are the main organizers, initiators and undertakers of their educational activities, but ideological and political educators of colleges and universities are also one of the main objects that should be subject to media literacy education. The specific research is carried out from two aspects: firstly, the media literacy education of ideological and political educators of colleges and universities should follow the principles of education law and reception law; secondly, the media literacy education of ideological and political educators of colleges and universities should adapt to the new media era. [27]

Through the above analysis, we can intuitively see that scholars have a relatively unified understanding in the relevant research, and they all believe that new media is a "double-edged sword", and we can foster strengths and circumvent weaknesses, integrate the advantages of new media itself into the system of ideological and political education of colleges and universities, and then enhance the influence of ideological and political education work. As the main force of ideological and political education of colleges and universities, teachers in colleges and universities should start with media knowledge, functions and application capabilities, make "Internet+ideological and political education" deeply integrated and continuously enhance the overall quality of the team of ideological and political education of colleges and universities. However, the research is also relatively inadequate, which is mainly manifested in two aspects. First, the lack of innovation in research cannot keep pace with the times. Second, the research content is too general and lacks pertinence.

\section{WAYS TO IMPROVE THE MEDIA LITERACY OF} IDEOLOGICAL AND POLITICAL WORKERS IN COLLEGES AND UNIVERSITIES IN THE NEW ERA

\section{A. Set up the Concept of Integrated Development and Explore the Integrated Development Mechanism of Ideological and Political Education of Colleges and Universities and New Media}

On December 8, 2016, General Secretary Xi Jinping pointed out at the national conference on ideological and political education: It is necessary to use new media and new technology to get the work moving, promote the high integration of traditional advantages of ideological and political work with information technology, and enhance the sense of the times and attraction. Therefore, we should establish the integrated development concept of traditional ideological and political education and new media, well coordinate the relationship between traditional ideological and political education and new media, integrate the education platform of new media, and construct a campus culture carrier of new media, build a team of ideological and political education with fairly good qualities of new media, and enhance the sense of the times and attraction of ideological and political work in colleges and universities. 
1) Objectively understand the characteristics of the two and do a good job in top-level design: First and foremost, the tradition and new media should be in a beneficial longterm coexistence relationship. Networking and informationization are the major trends of social development in the future, and new media, as a new form of traditional ideological and political education, will surely have extremely strong vitality. The development of the two modes of new media and traditional ideological and political education should permeate each other and embrace each other, and finally, they should be planned as a whole and develop together. Secondly, traditional ideological and political education and new media should also be in a beneficial complementary relationship. In our work at ordinary times, we should pay attention to adding appropriate forms of moral education to new media and pay attention to the healthy development of students' body and mind through various channels; do a good job in top-level design from the perspective of traditional ideological and political education to remove some false and incorrectly relaid erroneous information on the Internet so as to ensure the quality of new media; in the meanwhile, ideological and political educators should change their concepts, conscientiously sum up the advantages of new media, and reasonably insert them into the traditional ideological and political education work.

2) Renew ideas and construct a integrated development system of ideological and political education and new media in colleges and universities: New media technology has tremendously changed the ways college students receive information, transforming ideological and political education of college students from "planar" to "threedimensional". [28]Educators should integrate the education platform of new media and make use of WeChat, Micro blog, QQ and other social platforms to widely publish notices and all sorts of information needed by students; use public social platforms such as WeChat and Micro blog that receive a high degree of concern for college students to grasp the ideological trends of students in a timely manner, and do well in ideological guidance through comprehensive attention and individual intervention; build a management service website for campus students and transfer work related to students' day-to-day management, such as leave approval, award and superior evaluation and comprehensive evaluation, to the network system so that students can gradually accept the network system of the school. It is necessary to further refine the essence of traditional ideological and political education and express theoretical teaching contents in rich and colorful new media forms so that students can accept the contents in an easy and relaxed manner; further optimize the educational environment, and while ensuring the premise of imparting the basic ideas and concepts in the classroom, appropriately add some extracurricular group activities, and reasonably arrange oneto-one communication and network communication between teachers and students; strengthen emotional exchanges with students, integrate humanistic care into traditional ideological and political education and new media, start with observing the unique psychological characteristics of each student, accurately grasp students' needs, and practically enhance and improve ideological and political education for students.

3) Make use of the advantages of new media to enrich campus cultural life: By relying on the advantages of the construction of campus culture in colleges and universities, incorporate the educational functions of new media into the large system of ideological and political education in combination with virtual and reality forms and integrate the construction of campus culture in colleges and universities and the resources of ideological and political education for college students. For instance, carry out advance publicity of campaigns on WeChat and Micro blog, use WeChat and Micro blog live broadcasts, etc. to interact with students during the campaigns, and publish the publicity and campaign pictures on social websites such as Official Accounts after the campaigns; mobilize students to vote online for the entries, and set up comment sections and display the works and publicize the competitions while selecting the ranking of the works; by taking online publicity, micro blog and micro blog dynamics as one of the students' group assessment goals, and stimulate college students' enthusiasm in planning and organizing practical activities by virtue of the enthusiasm of college students for online new media; after the school's student management service website is accepted by most students, gradually add contents such as counselor micro blog and class culture display to strengthen the communications between ideological and political educators and school students and within students themselves, narrow the scope and carry out more targeted campus cultural activities.

4) Carry out media training and build a high-quality campus team of new media: In order for ideological and political education to truly adapt to the development and changes of the new media era, it is required to build a highquality team of new media and cultivate an ideological and political education team that is not only familiar with the laws of ideological and political work, has a high level of political theory, but familiar with the characteristics of network culture and has a good command of new media technologies, including ideological and political educators, student union cadres, association and class leaders, etc. For instance, while carrying out routine skills training, counselor forums or salons, establish the idea of educating people through the Internet, carry out information skills training, hold exchange meetings for the use of new media and so on in the team of college counselors, and integrate new media activities into their work at ordinary times; pay attention to the theoretical guidance and training of student union cadres, emphasize the importance of the use of new media, encourage and guide student union cadres to use new media 
to carry out student work, and strive to make the work object become a working force. For example, the strength of counselors in one state is limited, but after being forwarded by many student union cadres, their publicity coverage will grow exponentially, which can greatly enhance the publicity effect; attach importance to the position of association and class leaders in ideological and political education, guide them to lead the thoughts of ordinary students in their usual group activities, and use as many new media as possible to attract more association members and class students to pay attention to information through QQ groups, WeChat and other platforms so as to enhance the effect of ideological and political education.

\section{B. Innovate the Construction of Working Platform to Improve the Effectiveness and Pertinence of Ideological and Political Education of Colleges and Universes}

According to Tencent's data in the first quarter of 2018 , WeChat and MAU reached 1.04 billion, exceeding the scale of mobile netizens of 753 million in China, and at the end of 2017, WeChat has achieved a large area coverage of domestic mobile Internet users. In 2017, the number of people who log onto WeChat was 902 million, an increase of $17 \%$ over 2016 , WeChat has been sent 38 billion times a day, and WeChat has become one of the largest mobile traffic platforms in China. At the same time, based on the data of "2017 WeChat Economic Data Report" and "2017 WeChat User Research and Business Opportunity Insight", as of the end of 2017, WeChat Public Account had exceeded 10 million, of which 3.5 million were active accounts, an increase of $14 \%$ over 2016, and the monthly number of active fans was 797 million, a growth of $19 \%$ over the previous year, and Public Account has become one of the main functions on WeChat platform. [29]From the above data, it is not difficult to see that the construction of the official WeChat platform in colleges and universities is both a new direction for ideological and political education of colleges and universities, and the main field to improve the effectiveness and pertinence of ideological and political education of colleges and universities.

1) Build a student-centered service WeChat platform: The official WeChat public platform of colleges and universities is a new front for college students' work and ideological and political education to exert force in online publicity services. Such role positioning requires the official WeChat to go through an accurate overall planning, and after setting clear goals for its authority and credibility, base itself on the campus and look to the society, pay attention to the value of educating people and ideological guidance and further continuously expand the communication effect with guidance as the principle of development and practicality as the service center. The process of analyzing the needs of the audience and defining its own development path is complementary. The characteristics of the audience directly affect the content presented by the official WeChat platform, and the functional positioning of the official WeChat will also make meaningful screening of the audience's preferences. At present, the main audience for the official WeChat public platform of colleges and universities are young students after the 90s. Therefore, official WeChat of colleges and universities need to meet the needs of the audience through topics close to life and youth even more, and attract readers with friendly and vivid language, practical and useful contents and young and energetic perspective. Furthermore, the official WeChat public platform should be the existence of a "person" with the ability to communicate, rather than a cold propaganda tool of the student management department, it should have close interaction with fans in the message section and launch entity propaganda activities offline so that the student group can truly feel this "living" media charm, laying a foundation for public opinions in the development of student work in colleges and universities.

2) Clarify the agenda setting, adhere to the platform construction direction with content as king and various forms: Along with the development of the new media era, the network information environment becomes complex and complicated. College students are lack of the ability to judge values and are easily trapped in a state of lack of faith and spiritual confusion, so new media on campus undertakes the task of ideological and political guidance. Therefore, in the process of operation, the official WeChat should take the content construction as the foundation, not merely ensure the correct direction, but make the content break out of network information so as to realize the dissemination and penetration of information. In order to better spread the main theme and positive energy, the official WeChat of colleges and universities should aim at creating "phenomenal" excellent works and start from three aspects. First of all, in the process of innovation platform for ideological and political education, some official campus WeChat ignore ideological control in order to cater to the preferences of the post-90s audience and attract students' attention, blindly pursuing the high reading volume brought about by network-based expression in the operation process. Once the operators deviate from the agenda setting, they will deviate from the original intention of ideological and political education, thus affecting students' attitudes and behaviors. The official WeChat of colleges and universities should pay attention to agenda setting and value transmission, not only try their best to make core values deeply rooted in people's hearts in topic design through mainstream social media platforms on campus, but receive the effect of killing two birds with one stone. At the same time, within the content framework established, we should also grasp the relationship between pursuing novelty and leading thoughts rather than blindly pursue "network fashion", pay attention to guiding young people to base themselves on society and history, grasp the development pulse of the times, and establish correct world outlook, outlook on life and values; moreover, insist on content as king. Originality is a powerful guarantee of content, which 
gives vitality to the sustainable development of the campus media platform and promotes the innovation of the concept of educating people with new media on campus; furthermore, innovate the forms of expression. Diversified multimedia presentation forms can add brilliance to the creation of contents. The fast-paced life state and fragmented reading habits have brought forth the "era of picture-reading", and the development of mobile-end new technology has created more possibilities for us to improve our reading experience. The organic combination of pictures, audios, videos and hyperlinks, as well as the introduction of interactive elements, can all alleviate the tiredness and resistance of reading pure text contents and add beneficial presentation forms to high-quality text contents. The practice of the official WeChat of Jiao Tong University also indicates that works produced by careful original copy and rich presentation forms are most likely to trigger "phenomenal" clicks and forwarding to improve the communication effect.

3) Establish the concept of coordination and cooperation and integrate excellent resources: Most of the official WeChat public accounts of colleges and universities are guided by teachers and practically operated by student teams. For a team, long-term account operation requires continuous enthusiasm, professional competence and cooperation spirit. Actively exploring the management methods of operation teams and forming a set of sustainable development management mechanism are important topics for the healthy development of the official WeChat public platforms of colleges and universities. Adhere to the simultaneous development of system construction and talent team construction, grasp the reasonable selection and release of information, and construct the official WeChat of colleges and universities into "opinion leaders" with firm political stand, high theoretical level and good mass basis, thus making ideological and political education work full of vitality. The construction of the official WeChat public platform of colleges and universities should not "fight alone", but should highlight the effective integration of students' management resources, build an "alliance" of campus media, and establish a "matrix" for information dissemination. A single operation team of WeChat public platform has obvious limitations in selecting topics, and the richness of topics is closely related to the resource sharing of college students' work, fighting alone cannot form a joint force of public opinion, all operation organizations in the campus should carry out fully communication and negotiation and jointly establish a public opinion matrix of new media in colleges and universities. Besides, they should also break through the information barriers between schools, colleges, student organizations and other aspects and the operation teams of new media, conduct multi-party collaboration and jointly guide the public opinions on campus so as to form an online consortium for student work.

\section{CONCLUSION}

To sum up, the level of media literacy of ideological and political educators of colleges and universities exerts a direct impact on the work of new media and ideological and political education, and is becoming increasingly important with the passage of time. This requires that the vast number of ideological and political educators of colleges and universities must update their own media awareness and upgrade their media skills, which is not only a necessary quality of ideological and political educators of colleges and universities in the new era, but a requirement of the times and a direct reflection of their own political accomplishment. With respect to specific practice process, they should make full use of the advantages of new media communication, cultivate college students to establish and carry forward socialist core values, lead public opinions on campus, actively explore educational methods that are authoritative and professional and close to student groups, and enhance the substantial results of ideological and political education.

\section{REFERENCES}

[1] CNNIC: The 41st Statistical Report on the Development of Internet in China in 2018 - Development of Personal Internet Applications.

[2] Xi Jinping. Xi Jinping's Speech at National Conference on Ideological and Political Work in Colleges and Universities [EB/OL]. Ministry of Education of the People's Republic of China http://www.moe.gov.cn/jyb_xwfb/s6052/moe_838/201612/t20161208 _291306.html

[3] Xi Jinping. Report at the 19th National Congress of the Communist Party of China - Determining the Victory of Building a Well-off Society and Scoring the Great Victory of Socialism with Chinese Characteristics in the New Era [M].Beijing: People's Publishing House. 2017(10).

[4] Due to the limitation of space, there will be no further details on "propaganda work", "political work", "ideological work", "political education" and "ideological and political work". For details, please refer to "Discrimination of Concepts between 'Ideological and Political Work' and 'Ideological and Political Education' by Feng Gang and Zeng Yongping included in "Ideological and Theoretical Education" in January 2018.

[5] Ideological and Political Work Department, Ministry of Education. Theory and Practice of Ideological and Political Education for College Students[M].Beijing: Higher Education Press, 2009: 2.

[6] Qiu Weiguang. Introduction to Ideological and Political Education [M].Tianjin: Tianjin Peoples Publishing House.1988: 1.

[7] Wang Lizhan. Ideological and Political Education[M].Hangzhou: Zhejiang University Press 1989: 69.

[8] Lu Qingren. Principles of Ideological and Political Education [M].Beijing: Higher Education Press.1991: 4.

[9] Chen Binggong. Ideological and Political Education[M]. Changchun: Jilin University Press. 1992: 2-3.

[10] Liu Shulin, Chen Lisi. Principles of Ideological and Political Education for Young People [M].Beijing: China Youth Publishing House. 1999: 3.

[11] Zhang Yaocan, Zheng Yongting, etc. Modern Ideological and Political Education[M].Beijing: People's Publishing House 2001.

[12] Zhang Yaocan. Promoting the Transformation of Human Studies in the Research Paradigm of Ideological and Political Education [J].Studies in Ideological Education.2010: 7.

[13] Bu Wei. On the Significance, Contents and Methods of Media Education[J]. Modern Communication.1997(1): 29. 
[14] David Buckingham, Media Education-Literacy Learning Literacy Movement and Contemporary Culture, Polity Press in association with Blackwell Publishing Ltd, 2003, p36.

[15] (USA) W.James Potter.Media Literacy[M]. Li Degang, etc. (translator).Beijing: Tsinghua University Press.2012(10): 19.

[16] (USA) Stanley.J.Baran.Introduction to Mass Communication 8e Media Literacy and Culture[M]. He Zhaoyang (translator).Beijing: China Renmin University Press.2016(5): 18-20.

[17] Zhang Zhi'an, Shen Guolin. Media Literacy: A Comprehensive Educational Problem Worth Paying Attention to: A Review and Brief Comment of Media Literacy in Mainland China [J]. Journalism Review.2004(5).

[18] Zhang Guanwen, Yu Jian. On Media Literacy Education[J]. Chinese Vocational and Technical Education.2003(29).

[19] $\mathrm{Hu}$ Zhongqing. Media Literacy Education and Ideological and Political Education in Colleges and Universities[J]. Academic Forum. 2005(2).

[20] Wang Yanxia. Media Literacy Cultivation: A New Way of Ideological and Political Education for Chinese College Students during the Transitional Period[J].China Radio \& TV Academic Journal.2007(6).

[21] Wu Yong. Media Literacy Education under Internet Communication A New Field of Ideological and Political Education for Contemporary College Students[J].Academic Forum.2011(3).

[22] Ji Haiju. New Media Literacy Education: The New Mission of College Students' Ideological and Political Education [J]. Theory and Reform.2015(4).

[23] Luo Guogan. The Effective Combination of Media Literacy Education and Ideological and Political Education[J].Social Sciences in Guangxi.2016(11).

[24] Feng Xin. Research on Strategies and Approaches of Media Literacy Education for Ideological and Political Educators of Colleges and Universities in the Era of New Media[J]. Reform \& Opening.2011(3).

[25] Liu Yafei. A Study on Enhancing the Effect of Ideological and Political Education in Colleges by Referencing Communication Theories[D]. Degree Paper of Southwest University of Science and Technology.2016.7.

[26] Su Weigang. Strategies on Optimizing Media Literacy of Ideological and Political Educators of Colleges and Universities from the Perspective of "Internet + Education"[J]. Journal of Nanchang Hangkong University(Social Science Edition).2017(3).

[27] Luo Yuyun. Research on Media Literacy of Ideological and Political Educators of Colleges and Universities. Journal of Heihe University[J].2017(5).

[28] Xie Xiangxun, Peng Qiaoyin. On the Innovation of the Paths of College Students' Ideological and Political Education from the Perspective of New Media[J]. School Party Building and Ideological Education, 2011(11): 71-72.

[29] Statistics on the number of WeChat login users, the number of Wechat public accounts and the number of WeChat applets in China in 2018. [EB/OL].http://www.chyxx.com/industry/201805/645403.html, 2018$5-30$. 